\title{
Enhancing Sustainable Development and Regional Integration through Electrification by Solar Power: The Case of Six East African States
}

\author{
Sylvester Ngome Chisika and Chunho Yeom * (1)
}

check for updates

Citation: Chisika, S.N.; Yeom, C. Enhancing Sustainable Development and Regional Integration through Electrification by Solar Power: The Case of Six East African States. Sustainability 2021, 13, 3275. https:// doi.org/10.3390/su13063275

Academic Editor: Attila Bai

Received: 22 February 2021

Accepted: 13 March 2021

Published: 16 March 2021

Publisher's Note: MDPI stays neutral with regard to jurisdictional claims in published maps and institutional affiliations.

Copyright: (c) 2021 by the authors. Licensee MDPI, Basel, Switzerland. This article is an open access article distributed under the terms and conditions of the Creative Commons Attribution (CC BY) license (https:// creativecommons.org/licenses/by/ $4.0 /)$.
International School of Urban Sciences, University of Seoul, Seoul 02504, Korea; sylvesterchizika@gmail.com

* Correspondence: chunhoy7@uos.ac.kr

\begin{abstract}
The need to enhance energy access has led to the growing recognition of renewable energy sources in sustainable regional development. However, solar power, one of the less polluting renewable energy sources, continues to receive little attention in some developing countries seeking balanced development. Through a review of the literature, this paper examines the need for regional electrification by solar power and suggests measures to integrate regional energy policies and processes for balanced development. The authors find that there are many social, economic, and environmental benefits associated with using solar power. For instance, solar energy creates employment opportunities, reduces a country's foreign dependence, improves freedom of choice, improves a country's gross domestic product (GDP) and human development index (HDI), and is associated with improved environmental conservation. The region of East Africa is keen to reap these sustainable development gains through solar power electrification. The establishment of the East African Centre for Renewable Energy and Energy Efficiency constitutes an important melting pot for diverse renewable energy policies, in addition to confirming a commitment to solar power deployment. Moreover, some East African Community (EAC) states appear to be progressing faster towards regional solar power projects, while other states are lagging due to complex contextual challenges. However, the overall contribution of solar power to sustainable development remains low, as individual states appear to be focused on developing their national solar power projects. Nonetheless, there is great hope for regional development through shared solar power development if EAC states implement a number of regulatory and voluntary interventions.
\end{abstract}

Keywords: solar power; sustainable development goals; feed-in-tariff; solar power associations; regional grids

\section{Introduction}

Many developing countries are increasingly pursuing development toward greener economies. In the energy sectors of most countries, electrification appears to be transitioning from the use of fossil fuels to greener renewable energy sources, especially solar power. On the one hand, this green electrification trend is being shaped by the rising awareness of the negative impacts of fossil-fuel-powered energy systems, such as climate change and air pollution. On the other hand, the shift toward renewables is associated with the growing desire for energy security amid growing urbanization and a burgeoning energy demand, with its connection to competitiveness in the global community [1,2]. In this paper, the authors observe that, albeit with differences in regional patterns of electrification, from the perspective of sustainable development, growing solar electrification has arisen largely due to the increasing awareness of the environmental and socio-economic gains of renewable energy systems.

On the contrary, in the East African region, renewable energy resources, especially solar energy, remain under-exploited. There is a scarcity of information on how regional solar energy policies could be improved for greater synergistic effects on balanced regional 
development. Thus, this paper seeks to use literature review methods to compare the current status of solar power electrification among six East African countries (Kenya, Uganda, Tanzania, Rwanda, South Sudan, and Burundi) in order to provide suggestions on how solar energy policies could be improved towards greater integration and balanced development. The East African region was chosen for this study because it represents one of the areas that has immense solar power potential, presented by its favorable geophysical position along the equatorial region, where solar insolation is quite high in comparison with other regions such as European countries. Moreover, East Africa is a region that is greatly constrained in terms of reliable energy access, especially for those residing in rural areas, who constitute the largest proportion of the population. A report by the International Energy Agency (IEA) [2] showed that, in East Africa, for the fortunate people who have energy access, the electricity connection experience is sporadic and costly. There is thus an urgent need to alleviate these energy challenges in the region by harnessing integration through joint exploitation of renewable energy sources, especially solar energy resources.

\section{Solar Power Proliferation and Sustainable Development}

Solar energy technologies, including active technologies such as photovoltaics, nano grids, micro grids, and solar thermal technologies, have remarkable environmental, social, and economic benefits for society [3]. Hence, investments in these technologies are increasing. In 2007, US\$ 148 billion was invested in renewable energy development, compared to US\$ 33 billion in 2004 [3]. Moreover, up to 9.8 million people in 2016 and 10.3 million people in 2017 were engaged in the solar energy value chain (sale of products, assembly, and recycling) due to government policies supporting renewable sources, falling energy costs, and technological improvements [4]. Moreover, there are many health benefits associated with the reduced solid waste accumulation and air pollution. Studies show that 2.7 billion people globally still rely on wood biomass for energy, which significantly pollutes the air, unlike renewable energy resources such as solar resources. It has also been documented that solar power improves energy access, security, and resilience [5]. Studies have also projected that improved energy access from renewable energy such as solar power could improve the living conditions of more than $80 \%$ of households in the rural areas of developing countries and in island states that lack access to reliable electrification [5]. Sinha et al. [6] report that most solar products are made from materials that can be economically recycled, thus reducing solid waste accumulation and creating more recycling jobs.

Furthermore, solar products are technically secure and afford the user greater freedom to decide how to use the electricity to benefit themselves and the entire community [7]. Solar power and other renewable sources are also linked to reduced foreign energy dependence [8-10]. As a result, solar energy deployment has risen steadily from less than 9 gigawatts (GW) in 2007 to 290 GW in 2016, driven largely by favorable energy policies linked to the adoption of robust feed-in-tariff (FIT) policies [11-13]. These FITs have been linked to positive influences on the economic profitability of photovoltaic companies operating in Europe and Japan in addition to promoting social well-being. Furthermore, a Japanese study established that governmental renewable energy policies vary with a country's economic, social, and topographical conditions, but that the FIT system could be reasonably be applied to all citizens. By applying a carbon tax of $20 \%$, financial burdens on customers could be decreased by $32-45 \%$, with diminished expenditures on research and development for renewable energy compared to spending on nuclear energy research [14-16]. Other studies have also acknowledged that FIT policies are more efficient than alternative schemes in promoting renewable energy in view of the long-term financial stability provided to investors in renewable energy [17]. Studies show that over 73 countries had adopted some form of FIT policy as of 2014, contributing to high renewable energy investment security and guarantees. Thus, the authors observe that FIT policies are a key precondition for the successful proliferation of solar power. However, caution should be exercised, because FIT policy implementation in some jurisdictions may raise the system 
costs, cause tariffs to deviate from the prevailing market prices where tariffs are high, or affect the price of electricity [17]. Most importantly, the success of a FIT policy is dependent on the existence of a robust financial subsidy program, regional investments in social and economic welfare, technology-specific and location-dependent differentiation, and stable government regulations [17].

Nevertheless, there is growing cooperation between countries and regional trading blocs in developing robust policies, laws, and regulations for harnessing renewable energy sources such as solar energy resources to promote sustainable development. Many bilateral and multilateral cooperation instruments have been ratified between international organizations and regional governments to achieve sustainable development. Initially, before the global endorsement of sustainable development goals, the Kyoto protocol supported the implementation of many renewable energy policies through regional and country-specific clean development mechanism (CDM) projects, to address the then-rising environmental challenges that were impeding sustainable regional development. In the 21st century, many international and regional cooperation issues in renewable energy development have been explored under the Sustainable Development framework of the Sustainable Development Goals (SDGs). The 17 interconnected SDGs seek to address interconnected global challenges, including regional environmental degradation, poverty, and inequity (United Nations Development Programme website 2020). SDG 13 explicitly recognizes renewable energy as one of the climate actions for attaining global and regional sustainability. However, SDG 17 seems bolder and more robust and gives heavy credence to the topic of this paper by calling for partnerships aimed at achieving all 17 interconnected goals, which may be extended to the sustainable development of solar power. In fact, many countries and regions appear to be already exploring the SDG framework to advance the use of solar energy. For instance, in Europe, plans for regional development through solar energy appear to be more robust, deliberate, and urgent than in other regions in the world. The obligatory requirement of $20 \%$ renewable energy production for each state in the European Union, the National Renewable Energy plan of each state, and the European Union Cohesion Policy appear to be in harmony with solar power development and regional integration initiatives by enhancing social and territorial cohesion [18]. On the African continent, studies show that many countries are increasingly exploring solar energy resources for diverse reasons, but mainly as a countermeasure against environmental degradation and as a measure to improve socioeconomic conditions. According to the Oil Price website [19], Africa has become a hotspot for solar and other renewable energy forms. In 2019, the installed capacity for renewable energy was $12.6 \mathrm{GW}$. It was forecast to reach $16.8 \mathrm{GW}$ by 2020, with solar and wind projects dominating energy generation in Egypt, Algeria, Tunisia, Morocco, and Ethiopia. South Africa leads the continent, with a total solar power installed capacity of $2.4 \mathrm{GW}$, followed by Egypt and Morocco at $1.6 \mathrm{GW}$ and $0.8 \mathrm{GW}$, respectively. In addition, more than 40 out of 50 African states have installed or are in the process of installing solar power projects or other forms of renewable energy sources [19]. Studies reveal further that, in Africa, the promotion of regional solar power and renewable energy objectives are explored under the broader objectives of regional trading blocs, such as the South African Development Community (SADC) for south African states, the Economic Community for West African States (ECOWAS), and the East African Community (EAC) for East African states. This solar power proliferation in Africa appears to be attributed to many factors. For instance, the Oil Price website [19] reports that the cost of renewable energy is at an all-time low, and larger markets such as China, Europe, and India are closing in on their production targets. Thus, solar energy and other renewables will be cheaper because solar components will be readily available, thus creating a conducive environment for investments in regions such as Africa. However, the development of solar energy and other renewables has been challenging. Research has shown there to be an unfavorable political environment (especially in the case of political unrest after contested elections) as well as inadequate policy formulation and implementation and insufficient infrastructure; 
however, as demand for energy grows with the increasing population, many countries are turning to solar power [19].

In Asia, India's Green Energy Corridors program seeks to promote regional renewable energy use by connecting India with Bangladesh, Bhutan, Nepal, Myanmar, and Sri Lanka and is set to promote balanced regional development in that region [20] (ESI-Africa website 2020). Other studies have revealed a shortage of land, low levels of awareness of the efficacy of solar power (many people have the perception that solar plants are small and cannot generate electricity on the scale of conventional fossil-fuel-powered systems), and overpopulation are the major challenges affecting the advancement of solar power. Moreover, integrating electricity generated from renewables such as solar power with conventional power grids is technologically challenging in view of the weather dependence of solar power [20]. However, the construction of large-scale cross-border regional and international grids connecting several regions and solar power resources could be explored as a measure to address the seasonal variability of weather conditions that affect solar power [20]. Also, many multilateral organizations are supporting the establishment of cross-border grids. However, their main obstacles include issues regarding international cooperation (differing views on energy security), a lack of information and research on the costs and benefits of regional power trade, inadequate infrastructure, harmonization issues, and limited financing [20]. Pilot projects and model regional grids could also promote the development of regional energy sources [20]. Other studies suggest that public participation could be explored as a way to raise public awareness and approval of renewable energy sources such as solar power [21]. Regarding the low levels of awareness, e-learning approaches could be explored, given the current digital revolution where a majority of the population has access to smartphones [22]. However, it is important to bear in mind the different contexts by region, given the varying political, economic, and socio-cultural conditions in countries. The authors observe a high possibility for solar power exploitation as a propeller for regional development if more robust strategies are implemented.

\section{Materials and Methods}

The study explores existing knowledge of solar electrification, its current status, and the pattern of electrification in East African states directed toward sustainable development. Suggestions are offered on how regional renewable energy policies could be integrated for greater synergistic socioeconomic development. A literature review methodology was most suitable for this study, as it can help identify what has already been written on a topic, assist in determining the extent to which a research area reveals any interpretable patterns and trends, and help identify topics or questions that require further investigation [23]. Moreover, a literature review helps identify gaps in knowledge and provides the theoretical foundation of an empirical study [24], which are matters this study sought to address in exploring the status of solar power electrification in East Africa. There are many types of literature review, each having different steps for the review process. In this study, the authors applied the process and steps outlined by Templier and Paré [25]. In general, the steps involved in review processes are as follows:

(1) Formulating the objectives of the study to justify the need for the review, and defining key concepts at the heart of the synthesis;

(2) Searching the extent of the literature to determine where to find suitable materials for the review;

(3) Screening the literature for inclusion, which involves considering the applicability of gathered materials in order to determine their relevance, while taking measures to prevent mistakes and biases, to enhance objectivity;

(4) Assessing the quality of primary studies, whereby the scientific quality of gathered materials is further evaluated;

(5) Extracting data, which entails gathering applicable information and deciding what is relevant to the problem of interest; 
(6) Finally, analyzing data, where the information collected is collated, summarized, and aggregated, and evidence is compared. The extraction should be organized in a meaningful way that contributes to the existing literature on the topic. In this study, the steps identified above were applied as shown in Figure 1.

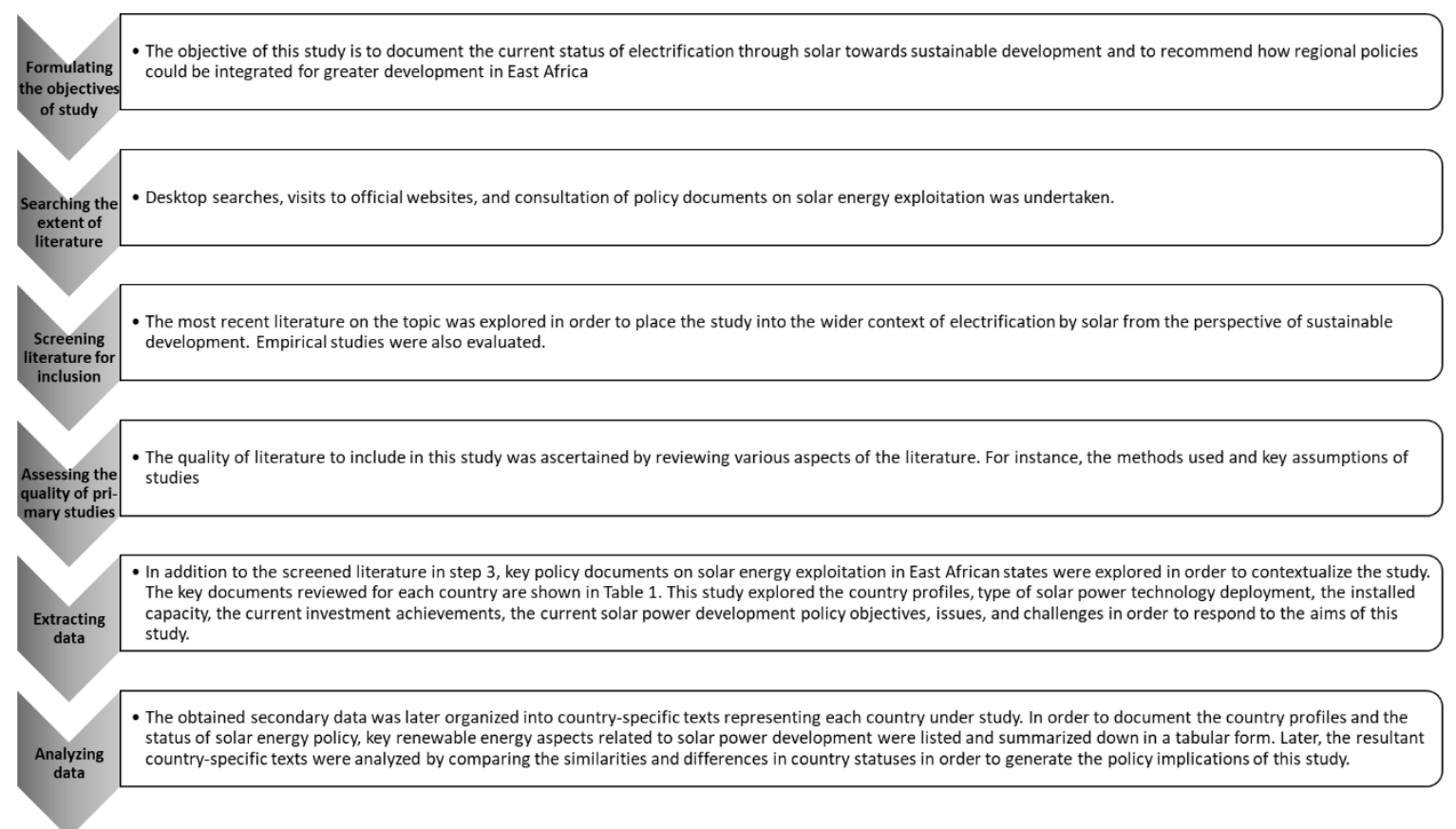

Figure 1. Steps in the literature review.

Table 1 shows a list of policy documents from six nations that were analyzed throught the study.

Table 1. Review of key solar energy policy documents.

\begin{tabular}{cccc}
\hline Document Name & Country & Source & Key Information Sought \\
\hline National Energy Policy [26] & Kenya & Kenya Power website & $\begin{array}{c}\text { Contextual information on the use of solar } \\
\text { power, such as solar power installed capacity } \\
\text { and existing solar power technologies } \\
\text { and challenges }\end{array}$ \\
\hline $\begin{array}{c}\text { Draft Energy (Solar PV Systems) } \\
\text { Regulations [27] }\end{array}$ & Kenya & $\begin{array}{c}\text { Energy and Petroleum Regulation } \\
\text { Authority website }\end{array}$ & $\begin{array}{c}\text { Contextual information on the use of solar } \\
\text { power, such as the objectives of the regulations }\end{array}$ \\
\hline National Energy policy [28] & Tanzania & Ministry of Energy website & $\begin{array}{c}\text { Contextual information on the use of solar } \\
\text { power, such as the energy mix and strategies } \\
\text { for solar power }\end{array}$ \\
\hline Draft Energy Policy [29] & Uganda & Ministry of Energy website & $\begin{array}{c}\text { Contextual information on the use of solar } \\
\text { power (technologies, strategies, } \\
\text { and challenges) }\end{array}$ \\
\hline Energy Policy [30] & Rwanda & Ministry of Energy website & $\begin{array}{c}\text { Contextual information on the use of solar } \\
\text { power, such as solar power installed capacity } \\
\text { and existing solar power technologies } \\
\text { and challenges }\end{array}$ \\
\hline Solar Energy Regulations [31] & Rwanda & Ministry of Energy website & $\begin{array}{c}\text { Contextual information on the use of solar } \\
\text { power (technologies, strategies, challenges) }\end{array}$ \\
\hline Energy law No. 1 [32] & Burundi & Ministry of Energy website & $\begin{array}{c}\text { Contextual information on the use of solar } \\
\text { power (objectives of the law and opportunities } \\
\text { for regional electrification) }\end{array}$ \\
\hline National Electric sector policy [33] & South Sudan & Ministry of Energy website & $\begin{array}{c}\text { Contextual information on the use of solar } \\
\text { power, such as solar power installed capacity } \\
\text { and existing solar power technologies } \\
\text { and challenges }\end{array}$ \\
\hline
\end{tabular}




\section{The Development Context for Solar Power in East Africa}

The East African Community (EAC), founded in 1967, is a regional intergovernmental organization comprising Kenya, Uganda, Tanzania, Rwanda, Burundi, and South Sudan (Figure 2). EAC was dissolved in 1977 due to differences in political and economic interests but was revived in 1999 under the EAC Treaty. Its main objectives are to deepen cooperation in the economic, political, and social spheres of development for mutual benefits and improved competitiveness. Cumulatively, EAC has massive energy resources that could be jointly harnessed for greater sustainable regional development. However, unlike other regional bodies in Africa, such as ECOWAS and SADC, EAC states have no specific protocol or policy regarding the exploitation of energy resources [34]. Nevertheless, the EAC Treaty recognizes the need for regional cooperation and development in the energy sector through Article 10 of the treaty, which calls for joint research initiatives to harness the use of energy resources [34].
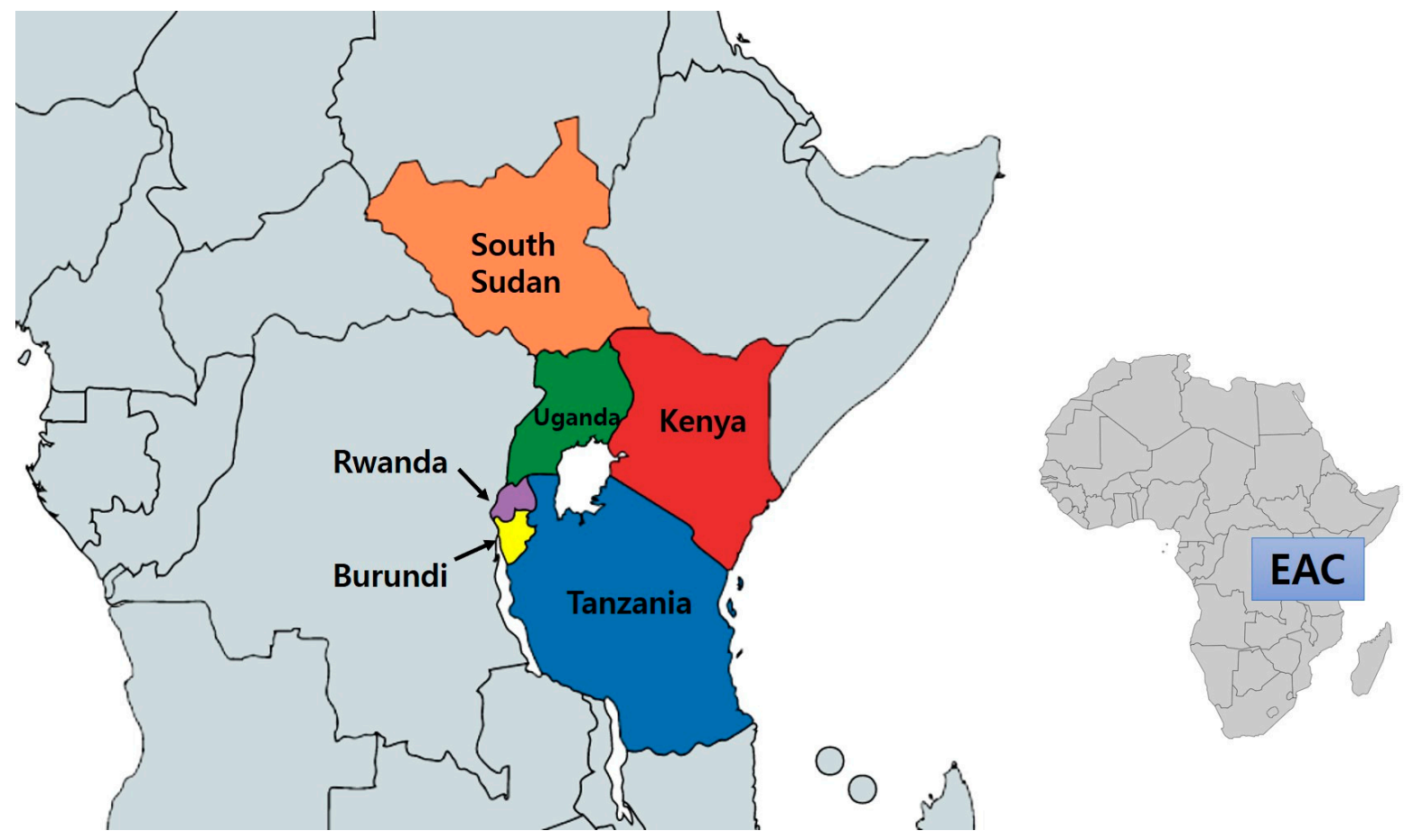

Figure 2. Map of East Africa showing the six member states of the East African Community (EAC) [35].

There are various initiatives aimed at harnessing renewable energy resources in the region. Developments in the renewable energy sector include the establishment of the East African Centre for Renewable Energy and Energy Efficiency (EAC REEE), whose aim is to improve energy access and energy security and promote the mitigation of the impacts of climate change. Exploring solar energy for regional development under this center represents an opportunity for enhancing regional competitiveness and energy security because, on average, the East African states have vast solar power resources; they receive sunlight for more than 320 days per year with an irradiance of approximately $2000 \mathrm{kwh} / \mathrm{m}^{2}$ annually, which is greater than in other regions of the world. In attempts to promote energyrelated investments, the EAC member states have signed various multilateral agreements with many international foreign investment bodies, such as the Multilateral Investment Guarantee Agency (MIGA) and World Trade Organization (WTO), to improve investor confidence in the member states in line with the energy charter provisions.

Interestingly, studies report that, overall, energy demand is projected to triple in Africa, including the EAC region, by the year 2030 [36]. If this holds true, it will be essential for EAC member states to diversify their energy production systems by introducing more renewable sources, such as solar power [36]. EAC governments appear to have recognized 
this challenge and are seeking to enhance investments in renewable energy sources. It can be seen that between 2010 and 2015, the region attracted approximately US\$ 4 billion in renewable energy investments, with US\$ 139.8 million being raised by companies seeking to expand off-grid electrification activities. In 2015, most projects were focused on solar power [36].

Using the MARS [36] dataset above, the authors compared the regional investment findings with individual states' GDP per capita in the same period, finding that the average GDP per capita for all EAC members combined appears to be rising together with the total worth of solar power investments, as shown in Table 2. This finding is critical to this topic, and the authors would have liked to explore it further, but due to the unavailability of solar power investment data in the subsequent period up to the year 2020, future studies are recommended.

Table 2. Total solar power investments and gross domestic product (GDP) per capita for EAC states.

\begin{tabular}{|c|c|c|c|c|c|c|c|}
\hline Country & Parameter & 2010 & 2011 & 2012 & 2013 & 2014 & 2015 \\
\hline \multirow{2}{*}{ Kenya } & Investment (US\$ million) & 1.177 & - & 256 & 494 & 1062 & 357 \\
\hline & GDP per capita (US\$) & 952 & 972 & 1137 & 1210 & 1316 & 1337 \\
\hline \multirow{2}{*}{ Rwanda } & Investment (US\$ million) & - & 92 & 6 & 36 & 24 & - \\
\hline & GDP per capita (US\$) & 583 & 646 & 704 & 705 & 723 & 728 \\
\hline \multirow{2}{*}{ Burundi } & Investment (US\$ million) & - & - & - & - & 274 & - \\
\hline & GDP per capita (US\$) & 234 & 250 & 252 & 257 & 275 & 306 \\
\hline \multirow{2}{*}{ Tanzania } & Investment (US\$ million) & 64 & 6 & 4 & 14 & 44 & 44 \\
\hline & GDP per capita (US\$) & 743 & 781 & 868 & 970 & 1030 & 948 \\
\hline \multirow{2}{*}{ Uganda } & Investment (US\$ million) & 50 & - & 34 & - & 3 & 134 \\
\hline & GDP per capita (US\$) & 623 & 603 & 669 & 689 & 739 & 709 \\
\hline \multirow{2}{*}{ South Sudan } & Investment (US\$ million) & - & - & - & - & - & - \\
\hline & GDP per capita (US\$) & 1536 & 1516 & 1180 & 1779 & 1323 & 1120 \\
\hline \multirow{3}{*}{ Total } & Investment (US\$ million) & 1291 & 98 & 300 & 544 & 1407 & 535 \\
\hline & GDP per capita & 4670 & 4767 & 4810 & 5611 & 5406 & 5147 \\
\hline & Average GDP per capita & 778.4 & 794.6 & 801.6 & 935.2 & 901.0 & 857.9 \\
\hline
\end{tabular}

Source: Authors' compilation.

Moreover, studies indicate that several companies have sought to exploit solar energy opportunities in the East Africa region. For instance, MaRS [36] reported that companies such as Off-Grid Electric and M-Kopa solar were rated as the top companies striving to promote solar energy in the region. Off-Grid Electric had over 100,000 customers in Tanzania and Rwanda using the "pay-as-you-go" program. M-Kopa solar had over 400,000 customers in Kenya, Uganda, and Tanzania. Other foreign companies from Canada have also invested in solar development in the region [36]. However, it will be interesting to study the motivation and strategies deployed by these companies and how their activities impact progress toward regional electrification using solar power resources.

In summary, the reviewed literature shows great potential for regional development through solar power (microgrids, nano grids, small pico systems, PV systems), which is already being explored. In addition to the development strides discussed above, a regional handbook for solar power taxation has been developed to guide common trading in solar power products [37].

However, in the authors' considered opinion, even though the East African region presents a diverse environment for the development of regional solar energy resources, the potential for development is immense. Some areas have irradiation concentrations reaching 2400 kilowatt-hours per square meter, representing some of the highest insolation 
in the world [37]. Moreover, the population of the region is increasing, with an average annual population growth rate of $2.7 \%$. Interestingly, the population is a relatively young population, with a growing middle class that frequently uses the mobile telephone infrastructure, which accelerates the demand for solar products. There are somewhat robust regional solar power governance and institutional arrangements. EAC, which is the overall structure for implementing regional policies, is divided into several hierarchical bodies: the Summit, Council of Ministers, and EAC Secretariat. The Secretariat is further divided into three working groups, with one focused on renewable energy sources. This working group is responsible for implementing programs on improving energy efficiency and preparing the renewable energy master plan. The development of the EAC regional power master plan for 2013-2038 is the most outstanding indication of the need for sustainable regional development through energy projects. It has enabled EAC to prepare standard contracts that promote cross-border electrification, focusing on establishing a common electricity market for power trading in the region. However, the formation of the East African Centre for Renewable Energy and Energy Efficiency (EA REEE) holds immense potential for integrating solar energy issues in the region [37]. Its overall objective is to work for energy security and access as well as the mitigation of the impacts of environmental degradation. In order to achieve the specific objectives of the Centre, up to five activities for promoting renewable energy have been specified, which include but are not limited to joint policy formulation, mutual capacity building and research on renewable energy issues, joint knowledge management, awareness creation, and joint business planning, investment, and promotion of the renewable energy sector by establishing renewable energy associations.

\subsection{Kenya}

Kenya is a member of the East African Community (EAC). According to Kenya National Bureau of Statistics (KNBS) [38], the country has 47 million people, with the highest GDP per capita, estimated at US\$ 1710.5, and the highest Human Development Index (0.579) in the EAC. Kenya has massive energy resources and is the largest producer of renewable energy sources, such as geothermal. However, there is still a significant challenge regarding electrification, with biomass energy accounting for approximately $68 \%$ of its energy mix. The general energy sector is liberalized and allows other actors to participate in producing and distributing electricity. The liberalization of the energy sector was pursued to attract investments by reducing government bureaucracy and enhancing negotiations for incentives and other protections for foreign investments. The other key study parameters of interest in this paper are as highlighted in Table 3.

Kenya is considered a feasible site for the proliferation of solar energy technologies (PV systems, micro grid, nano grids, and related technologies) [39]. Currently, the country is in the process of developing regulations geared toward ensuring the sustainable utilization of solar power resources through the Draft Energy Solar Photovoltaic Systems Regulation of 2020 [39]. In 2020, the country revised its Nationally Determined Contribution (NDC), with commitments to cut greenhouse gas emissions from $30 \%$ to $32 \%$ by the year 2030 . Thus, the country has prioritized increasing the share of renewables, including solar power, in the electricity generation mix as a key activity for mitigation of and adaptation to climate change. These efforts are increasingly seen as a move to favor clean energies and reduce reliance on fossil-fueled energy systems, as the country gears toward implementing a green economy strategy for achieving sustainable development. The regulations set the requirements for the quality of solar products to be imported as well as the licensing of contractors engaged in solar power distribution and the installation and maintenance of photovoltaic systems [39]. The regulations that have been enacted mandate the Energy and Petroleum Regulatory Authority (EPRA) to undertake occasional inspections to determine compliance with the rules and impose hefty fines on those who contravene the regulations. There are already various solar technologies currently under deployment in the country, including but not limited to photovoltaics that generate thermal energy and concentrate solar energy. As of 2017, there were several proposals for solar energy projects in different 
parts of the country. However, notably, Kenya has 56.25 MW of installed solar capacity. In addition, the country owns the largest solar generation plant, worth Kenyan shilling (Kshs.) 13 billion, in Garissa County. The solar plant has more than 200,000 PV panels and produces $50 \mathrm{MW}$. The project is owned by the government and is anticipated to generate up to $2 \%$ of the country's energy mix [40].

Table 3. The development context for solar power in the EAC region.

\begin{tabular}{|c|c|c|c|c|c|c|}
\hline Parameter & Kenya & Tanzania & Uganda & Rwanda & Burundi & South Sudan \\
\hline Population & 47 million & 56 million & 42 million & 12 million & 11 million & 10 million \\
\hline Land area $\left(\mathrm{km}^{2}\right)$ & 580,367 & 945,087 & 241,037 & 26,338 & 27,834 & 619,745 \\
\hline $\begin{array}{c}\text { GDP per } \\
\text { capita (US\$) }\end{array}$ & 1710.51 & 1050.68 & 642.78 & 772.94 & 271.75 & 1119.65 \\
\hline $\begin{array}{c}\text { Human } \\
\text { development index } \\
\text { (HDI) }\end{array}$ & 0.579 & 0.538 & 0.528 & 0.536 & 0.423 & 0.388 \\
\hline Forest cover $(\%)$ & 7.4 & 65.6 & 15.2 & 30 & 10.93 & 30 \\
\hline $\begin{array}{l}\text { Biomass energy (\%) } \\
\text { of energy mix }\end{array}$ & 68 & 90 & 93 & 84 & 94 & - \\
\hline $\begin{array}{l}\text { Price of } 1 \mathrm{kwh} \\
\text { of electricity } \\
\text { (household- } \\
\text { US\$ cents) }\end{array}$ & 0.205 & 0.099 & 0.182 & 0.261 & 0.33 & 0.003 \\
\hline $\begin{array}{l}\text { Price of } 1 \mathrm{kwh} \\
\text { of electricity } \\
\text { (industrial- } \\
\text { US\$ cents) }\end{array}$ & 0.163 & 0.102 & 0.155 & 0.097 & 0.33 & 0.03 \\
\hline Governance System & $\begin{array}{l}\text { Devolved-two-tier } \\
\text { government }\end{array}$ & $\begin{array}{l}\text { Unitary presidential } \\
\text { democratic state }\end{array}$ & Presidential system & $\begin{array}{l}\text { Semi-presidential } \\
\text { system }\end{array}$ & $\begin{array}{l}\text { Transitional } \\
\text { presidential } \\
\text { democracy }\end{array}$ & Presidential system \\
\hline $\begin{array}{c}\text { Year of } \\
\text { Independence }\end{array}$ & 1963 & 1961 & 1962 & 1962 & 1962 & 2011 \\
\hline Refugee population & 1.1 million & 276,046 & 1.7 million & 159,228 & 42,200 & 2.2 million \\
\hline
\end{tabular}

Source: Author's compilation from multiple sources.

Nevertheless, there are growing initiatives to expand the use of solar power in the country. Over 250 households in 14 devolved units around the country are to be connected to solar power through a partnership between the government and the World Bank in the amount of US\$150 million. In addition, parties importing solar products enjoy tax exemptions and incentives that make their products affordable in the market. It is hoped that these solar power gains will be sustained through the Kenya Renewable Energy Association (KEREA). Furthermore, the tariff paid for the Garissa plant is cheaper than the tariff for solar energy under the feed-in-tariff policy, currently at US $\$ 0.075$ per kilowatthour. The feed-in-tariff has been employed largely to attract private-sector efforts to promote the development of solar energy resources for the national grid. While there are variations in FIT rates and durations for power purchase agreements for small and large renewable energy projects, in general, the FIT policy prescribes 20 years from the date of first commissioning. Solar energy resources are also to be used for off-grid supply to displace fossil fuels based on thermal generation of electricity for household supply, especially in rural areas [41].

Solar power projects have positively impacted the general well-being of residents. For example, investments by M-Kopa Solar, a local solar power company operating in Kenya's rural areas, has reported financial inclusion for solar power customers of up to US\$ 365 million by unlocking loan opportunities for over 1.5 million clients, improving energy access, and saving up to US\$ 428 million for customers while avoiding over 1.8 million metric tons of carbon dioxide and black carbon emissions; up to $50 \%$ of the 1 million clients use M-Kopa Solar products to raise their incomes. Solar products have enhanced the digital inclusion of over 150,000 customers connected to the internet with M-Kopa-funded smartphones [42]. 
However, in general, Kenya has been castigated for not devoting sufficient attention to solar energy, largely due to the lukewarm approach amongst public institutions mandated to execute power purchase agreements and the growing recognition that geothermal development could be cheaper. There are also problems related to technologies for the storage of solar energy and concerns that the Draft Solar power regulations of 2020 are punitive, biased against solar power to slow its uptake in order to save Kenya's power from imminent collapse. Kenya Power is a state-owned monopoly mandated to distribute grid electricity to consumers and, in the process, generate revenue for the government. However, it has been reported that Kenya Power, which relies largely on the sale of thermally generated power, has faced competition from the recent aggressive uptake of solar power by many industrial-scale consumers, who account for $54.8 \%$ of electricity sales for Kenya Power, depriving it of much-needed revenue. In addition, over 2.3 million households are using solar lighting systems. EPRA's press release of 2020 contested these "Kenya Power saving allegations", insisting that the regulations are in the interest of the Kenyan people, and has called for public participation and submission of comments [43].

\subsection{Rwanda}

In terms of general energy issues, Rwanda's total energy consumption is dominated by biomass ( $84 \%)$, and energy access is a major problem [44]. The general energy sector is liberalized and allows other actors to produce and distribute electricity within and outside Rwanda's territory. The electricity law protects investors' entitlements and prescribes compensation to be paid to property owners before property expropriation.

The country has vast solar power resources, with a potential of $4.5 \mathrm{kWh} / \mathrm{m}^{2}$ per day and an estimated five peak hours of sun. The country's solar installed capacity is 12.23 MW, currently derived from four solar power plants: Jali, Rwamagana, Ndera, and Nasho $[45,46]$. There are plans to accelerate the current solar power program in the country to reduce the costs of production and leverage available energy resources, which have roused interest in the private sector despite the limited technical capacity. For instance, in 2014, the government established somewhat tough and punitive regulations for dealers in solar products to protect consumers against unscrupulous businesses [47]. In 2018, the government signed a memorandum of understanding with Mara Corporation and SB Energy Corp from Mauritius to develop a $30 \mathrm{MW}$ plant with a storage facility. Other government efforts to promote solar power users are focused on the Rural Electrification Strategy of Rwanda of 2016, where stand-alone photovoltaics are advocated for use in rural areas. This strategy appears to be in line with the country's energy sector strategy, where universal access to electricity is anticipated by 2024 , with over $48 \%$ of households connected to off-grid systems in the country. The energy sector plan sets ambitious targets for solar energy. Perhaps more importantly, the plan outlines the implementation of EAC energy sector priorities as one of its targets, which could be relevant for regional development. There is also an action plan to promote regional integration opportunities through electricity import and export to villages in Uganda that border Rwanda [48]. The country is also home to the Africa Solar Industry Association [49].

\subsection{South Sudan}

South Sudan has massive energy resources but has the lowest electrification rates per capita in sub-Saharan Africa [50,51]. This is largely attributed to the underdevelopment of the energy infrastructure in the country, owing to the fact that the country gained independence on 9 July 2011, after a long period of civil war. Therefore, more time and resources will be required to establish a reliable energy infrastructure.

South Sudan has immense potential for economic development through solar power, with donors and the private sector taking a leading role [52]. On average, the country has up to $9 \mathrm{~h}$ of sunshine per day, but its exploitation remains lacking. As of September 2019, the Government of South Sudan had announced its intentions to tap the immense renewable energy sources of the country by launching a plan aimed at defining the country's 
renewable energy course of development, and there are plans to secure US\$990,000 for a renewable energy program [53]. It is anticipated that the development of solar power would decouple economic growth from the geopolitics of oil and gas [54]. Nonetheless, the literature indicates that photovoltaics are the main technological means for tapping solar power in the country, with a total installed capacity of 2 MW. Most of this installed capacity is utilized in the telecommunication industry [55]. Even though there is a shortage of literature on solar energy development in South Sudan, studies such as Omer [55] indicate that renewable energy resources are clearly integrated into the national energy policy. Moreover, while there appear to be no efforts aimed at enhancing regional integration through solar power, there is growing investment in solar energy resources.

\subsection{Tanzania}

Tanzania is the largest country in EAC in land area as well as the most populous country in the region, with 56 million people. Tanzania has the highest forest cover, estimated at $37.7 \%$, and has the second-lowest household electricity tariff, at US\$ 0.099 per kilowatt-hour. The other contextual parameters of interest to this paper are shown in Table 3. The country has massive energy resources. However, there is still a significant challenge for electrification, with biomass energy accounting for approximately $90 \%$ of its energy mix [56,57]. Solar power development in Tanzania has been dominated by photovoltaics used for electrification in home-based systems and small-scale commercial systems, which make up about $70 \%$ of the country's installed solar capacity [58]. The general energy sector is liberalized and allows other actors to participate in producing and distributing electricity. The liberalization of the energy sector was pursued to attract investment by reducing government bureaucracy and enhancing the environment for negotiations for incentives and other protections for foreign investments.

Tanzania has vast solar resources, exceeding $5 \mathrm{kwh} / \mathrm{m}^{2}$ per day [59]. Solar power appears to be the dominant power source for rural electrification, providing energy to $64.8 \%$ of the rural population. This development of solar power has been propelled largely by NGOs and the Tanzania Solar Energy Association. The solar energy sector, especially the photovoltaic market segment, has grown significantly due to increasing environmental awareness and government recognition of the potential for solar power in grid development and the growing purchasing power of the people [60]. However, no large-scale investments in solar power infrastructure have occurred in the country. Still, institutional arrangements for its development appear to be robust, gauging from the litany of existing enabling legislation and policies. The country has a FIT policy to promote the use of renewable energy sources, including solar power, by promoting investor confidence [60,61].

\subsection{Uganda}

Uganda is the third most populous country in the EAC region and has the fourth largest inland area. The country has $15.2 \%$ forest cover. The other contextual variables of relevance to this paper are highlighted in Table 3. The country has massive energy resources. However, there is still a significant challenge for electrification, with biomass energy accounting for approximately $93 \%$ of its energy mix $[62,63]$. The general energy sector is liberalized and allows other actors to participate in the production and distribution of electricity. The liberalization of the energy sector was pursued to attract investments by reducing government bureaucracy, enhancing decentralization, improving efficiency, and enhancing the environment for negotiations for incentives and other protections for foreign investments.

Solar energy is the most promising source of renewable energy in Uganda. The country is located along the equator and has high levels of solar insolation, which is compatible with a variety of solar technologies. The solar irradiation for Uganda ranges between 1825 and $2500 \mathrm{kwh} / \mathrm{m}^{2}$ per year [62,63]. Even though solar development in the country began as early as the 1980s and has been promoted by the government and development partners, the current use is relatively low. However, it has been improving since the introduction 
of new solar products from Asia, government support through FIT regulations, and the introduction of the Rural Electrification Strategy Plan in 2001. In general, the proliferation of solar energy appears to be on the rise, with the Uganda Solar Energy Association seeking to become a vibrant institution, providing solar energy solutions that match national, regional, and international standards [64].

\subsection{Burundi}

Burundi is an equatorial country with vast solar energy resources. The average annual sunshine fraction is $2000 \mathrm{kWh} / \mathrm{m}^{2}$ per year. However, there is still a significant challenge for electrification, with biomass energy accounting for approximately $94 \%$ of its energy mix [65]. Following policy and legislative reforms in the country, liberalization led to the introduction of public-private partnerships in power generation and distribution. The country has an investment code that sets incentives for the energy sector by reducing taxes on goods used to establish new businesses. However, there are few direct fiscal incentives in the energy sector [66].

Photovoltaics dominate solar energy deployment in Burundi, with applications in rural electrification, solar pumps, stand-alone photovoltaic generators, grid-connected photovoltaics, and hybrid photovoltaics in remote areas. The liberalization of the energy sector also provides immense opportunities for developing renewable energy resources in the country integrated with the development aspirations of East Africa [67]. In the long- and medium-term, existing policy seeks to connect Burundi's electrical grid with solar power stations [68]. There are growing efforts to promote investment in solar energy development, but as of 2014, the country had not established structures to implement FIT policies. However, it is hoped that issues of regional solar power development can be championed through the Burundi Renewable Energy Association [69].

The country-specific development attributes indicated in Table 3, especially population, HDI, GDP, and forest cover (environment), are important in analyzing and understanding a country's energy status in terms of the quality and volume of consumption. Yumashev et al. [70] evaluated the influence of HDI on energy consumption in selected countries and found that the size and rating of HDI influence economic growth variables such as urbanization, GDP, the share of clean energy consumption in the population, the level of socioeconomic transformation, and the share of research and development expenses. Moreover, the volume of energy consumed affects HDI and is an important factor for sustainable development. As seen in Table 3, Kenya has the highest HDI and the highest GDP per capita, while Burundi has the second lowest HDI and the lowest GDP per capita. Moreover, Kenya has the lowest forest cover and lowest biomass index, with fairly high household and industrial electricity prices. South Sudan has the lowest household and industrial electricity prices, with a fairly high forest cover of $30 \%$ and high GDP per capita, but it appears to have the lowest HDI. From these observations, it will be interesting in the future to conduct correlation analyses with these variables in the case of the six East African countries and share the policy implications.

\section{Discussion}

Electrification by solar energy is gaining momentum in many developing countries seeking to transition toward green economies and sustainable regional development. This trend is attributed to many contextual factors, such as the growing consciousness of the negative impacts of fossil fuels; increased awareness of the benefits of solar technologies, which can contribute to community development in many respects; the increasingly positive attitude toward solar power; the favorable policy environment provided by governments; and the quest for energy security by countries, regions, and trading blocs [2,4]. Consequently, there have been massive investments and formulation of policies that support renewable energy sources [3-5,11,71]. Policy enhancements have largely involved reviewing obligatory and voluntary fiscal and non-fiscal incentives across regions, leading to increased integration and regional development. For instance, the European Union is more specific 
and uses absolute targets and regulatory obligations for member states [3]. These diverse policy approaches represent a great opportunity to transition to greener economies and sustainable regional development.

Furthermore, the literature shows that there are different patterns in strategies for regional electrification by solar power. The provision of incentives, tax exemptions, lowinterest loans for solar power investors, innovative product purchase agreements such as "pay-as-you-go", capital investment subsidies, and government goodwill are the most overt indications of the inclination toward solar power in countries seeking to rely on renewable energy for sustainable regional integration and development. Interestingly, the feed-in-tariff policy appears to be the most important policy factor in promoting sustainable regional development through electrification by solar power [11,14-16,64,71].

Furthermore, depending on the strategies applied in a particular country (whether regulatory or voluntary), solar energy deployment appears to be yielding many environmental, social, and economic benefits to the global community through reduced carbon emissions, reduced pollution, reduced accumulation of solid waste, improved employment opportunities, improved local incomes and livelihoods, improved freedom of choice in electricity alternatives, reduced energy costs, improved energy access for rural communities, reduced dependence on foreign energy resources, and improved cooperation between countries [2-9,71]. Thus, many countries are coalescing into regions and regional trading blocs to sustainably explore these under-exploited renewable energy resources. For example, in Africa, solar power resources are harnessed under the auspices of trading blocs such as SADC in southern Africa, ECOWAS in West Africa, and EAC in the East African region [34]. In Asia, there are plans underway for the implementation of India's Green Energy Corridor program, which includes solar power development and seeks to connect and integrate India with the economies of five countries (Bangladesh, Bhutan, Nepal, Myanmar, and Sri Lanka) [20]. In the European continent, the European Union (EU) seeks to enforce a regulation that stipulates that at least $20 \%$ of final energy consumption should be based on renewable energy among member states $[2,4,12,71]$. These examples demonstrate a future of solar power electrification as a strategy for sustainable regional integration, cooperation, and development.

Equally, there are several challenges in achieving regional development through solar power [20]. However, the greatest challenge for countries and regions seeking to jointly explore resources, such as solar power, was found to be the exploration of the many diverse regional development processes to maximize available resources, without compromising sustainable regional development. However, the authors consider that the Energy Charter Treaty framework and the 17 sustainable development goals could provide a flexible window of opportunity within which countries and regions can conduct such an exploration in the quest for regional development. SDG 17 on the need to increase energy access could provide a policy platform for partnerships that seek to enhance the use of solar power resources across regions.

The six East African countries under the umbrella of the East Africa Community (EAC) exemplify the above findings and demonstrate the potential for universal energy access through electrification with solar energy sources for greater integration and sustainable regional development. Some significant similarities and differences favor electrification by solar power resources for regional integration and development. However, solar power uptake appears to vary greatly despite the many biophysical, socioeconomic, political, and cultural similarities highlighted in Table 3. Notably, the six EAC member states are located in favorable geographical locations along the equator. The almost year-round solar insolation is greater than in other regions such as Europe, where solar insolation varies greatly or may be absent in some seasons [34]. As specified in Table 3, the region has one of the biggest combined refugee populations in various UN or other aided camps, which could be engaged in the solar power value chain to contribute to economic growth and cooperation in the region. Such engagements with refugee populations could stimulate the morale of the displaced persons and help in a positive environmental cause, leading 
to nation-building. The reviewed literature shows that the solar power value chain is operated by many actors, thereby creating employment opportunities that contribute to improved quality of life and a peaceful coexistence amongst communities.

Nevertheless, there have been some significant investments in solar power projects by private local and international companies across the region, following individual countryspecific energy policy improvements and general goodwill on the part of EAC governments. The data in Table 2 suggest strongly that solar investments are bound to improve economic development in the region, as have such groups as MaRS [36] and EAC [34]. The results also show that all EAC member states have policies and plans that favor the development and exploitation of on- and off-grid solar energy resources, with a growing tendency to install off-grid solar systems in rural areas (Table 3).

Moreover, there are efforts to establish various politico-administrative structures to promote the use of renewable energy resources for cross-border electrification, exemplified by the development of the EAC Regional Power Master Plan 2013-2038. Moreover, the East African Secretariat on Energy and the accompanying institutions appear to guide establishing regional power pools to increase cross-border electrification in line with the East African strategy of scaling access to modern energy services (2006). However, the authors believe that the boldest and most deliberate attempt at promoting regional development through renewable energy sources, including solar power, is the establishment of the East African Centre for Renewable Energy and Energy Efficiency, whose objective is to improve energy access and security and promote the mitigation of the negative impacts of climate change among EAC member states. The activities of the East African Centre for Renewable Energy and Energy Efficiency are likely to be sustained through solar power development in the future, because they appear to be in line with the renewable energy objectives of many environmental multilateral agreements that are central to the activities of many international foreign investment bodies, such as the Multilateral Investment Guarantee Agency (MIGA) and World Trade Organization (WTO). Furthermore, publication of the Solar Power Taxation handbook will serve to enhance interstate trade in solar products. This harmony in activities, objectives, and actions is meant to promote regional competitiveness, thus providing solar power investors with confidence in the region. Hence the approximately US $\$ 4$ billion in renewable energy that the region has attracted, with US\$ 139.8 million being raised by companies expanding off-grid activities in 2015, with solar power dominating, as shown in Table 2.

However, some EAC member states appear to be progressing faster with in-country solar power investment development than others. Kenya and Rwanda appear to be the front runners, while South Sudan and Burundi had the lowest levels of solar power investment as of 2015 [36]. Kenya's increased proliferation of solar power may be attributed to the following: the vast solar energy potential, especially in the drier northeastern parts of the country having high insolation; liberalization of the energy sector and existence of robust solar power development policies, such as the Draft Energy (Solar Photovoltaic Systems) Regulation of 2020, which seeks to protect consumers from unscrupulous business firms; the provision of incentives in the national energy policy, such as friendly FIT opportunities for investors in renewable energy resources; the need to reduce the use of biomass energy resources; somewhat aggressive government investment and leadership in solar power development (such as the investment in Garissa County); somewhat aggressive marketing campaigns by consumer organizations such as the Kenya Renewable Energy Association (KEREA), promotion by local and international private companies such as M-Kopa Solar, and renewed commitment to NDC; and growing dissatisfaction with grid reliability due to management inefficiencies at Kenya Power. These preconditions are similar to the findings of Ayoub and Yuji [15], who argued that similar factors could explain the success of many solar power development policies. Despite the good progress toward solar power development, Kenya still has higher energy prices for industrial and household consumers than fellow EAC member states. Whereas the authors cannot accurately point to the exact cause of the high energy prices, the authors speculate that this may be attributed 
to management inefficiencies at the state-owned power distributor (Kenya Power) and the lukewarm adoption of alternative energy sources such as solar power. In addition, despite the scarcity of comprehensive studies on cost-benefit analyses for FIT policies, Kenya's high energy costs could also be attributed to the challenges of implementing FIT policies. In other jurisdictions, FIT policies have been found to distort system costs or increase electricity costs $[16,17]$.

Nonetheless, there is progress toward regional development, given the country's active involvement in the EAC Secretariat and the robust National Energy Policy of 2018, which seeks regional cooperation through options such as direct sale and net metering for solar power (see Table 3). Similarly, Uganda has a somewhat robust regional cooperation strategy for solar power exploitation in view of the provisions of the Draft Energy Policy, 2019. The country seeks to develop a framework for exporting surplus solar power through direct sales and net metering approaches, as indicated in Table 4. Moreover, the FIT policy, government involvement, and the Uganda Solar Energy Association's activities and investments by development partners have been key in promoting solar power development.

Approaches similar to those of Kenya and Uganda are being pursued by Rwanda, which is seemingly making bolder efforts toward solar power development and proliferation using the FIT policy arrangement, as is shown in Table 4. The country appears to have a more robust plan, which is likely to hasten the promotion of regional integration and development with solar power in the EAC region through plans to export solar power to villages in Uganda along the border, as outlined in ESSPR 2013-2018. This cross-border solar power distribution plan represents a major opportunity to establish cross-border solar power grids and increase regional solar power investments [20]. Moreover, this regional integration opportunity appears to be in line with SDG 17, the aspirations of EAC cooperation on energy issues, the desires of many private local and international solar power development partners, and the mandate of the existing East African Centre for Renewable Energy and Energy Efficiency on joint exploitation of renewable energy sources, including solar power, for balanced regional development. Furthermore, Rwanda exemplifies the opportunities for promoting regional integration and development beyond the EAC region, through the activities of the Africa Solar Industry Association (ASIA). Similar solar-power-specific associations could be established in Kenya to promote the interests of solar power consumers.

In Tanzania, solar power proliferation appears to have been promoted to a moderate degree largely through energy sector liberalization, a seemingly robust FIT policy, and activities of NGOs and the Tanzania Solar Energy Association. In Burundi, the liberalization of the energy sector appears to have afforded opportunities for regional development through solar power. However, large-scale proliferation appears to be low due to the absence of a FIT policy. The FIT policy has been identified as the most important precondition for promoting solar power in many regions across the world $[13,14,16]$. Similar conditions may also explain the case of electrification by solar power in South Sudan. However, the authors note that as this country only attained independence in 2011, it is perhaps in the process of establishing institutions to facilitate the formulation of appropriate renewable energy policies, thus exemplifying the impact that political instability and war could have on developing regional infrastructure, including solar power development. Therefore, it would be unfair to compare South Sudan with the rest of the EAC states, who attained independence in the 1960s. However, South Sudan appears to be making progress toward opening up its solar power resources. 
Table 4. Summary of solar energy issues in EAC states.

\begin{tabular}{|c|c|c|c|c|c|c|}
\hline Thematic Area & Kenya & Tanzania & Uganda & Rwanda & Burundi & South Sudan \\
\hline $\begin{array}{l}\text { Key policy document on } \\
\text { solar power }\end{array}$ & National Energy Policy 2018 & National Energy policy 2015 & Draft Energy Policy 2019 & Energy Policy 2015 & Energy law No. 1/014 & $\begin{array}{l}\text { National Electric sector } \\
\text { policy } 2007\end{array}$ \\
\hline $\begin{array}{l}\text { Policy aims at cooperation } \\
\text { on solar energy }\end{array}$ & $\begin{array}{l}\text { Provide a framework for } \\
\text { connection of electricity } \\
\text { generated from solar energy } \\
\text { to national and isolated } \\
\text { grids through direct sale or } \\
\text { net metering }\end{array}$ & $\begin{array}{l}\text { Provide a framework for the } \\
\text { use of renewable } \\
\text { energy resources }\end{array}$ & $\begin{array}{l}\text { Aims at developing a } \\
\text { framework for exporting } \\
\text { surplus solar energy from } \\
\text { self-generating sources } \\
\text { through direct sales } \\
\text { and net metering }\end{array}$ & $\begin{array}{l}\text { Provide a framework for the } \\
\text { exploitation of solar power } \\
\text { through FIT policy }\end{array}$ & Non-existent & Non-existent \\
\hline $\begin{array}{l}\text { FIT Guidelines for the solar } \\
\text { energy present }\end{array}$ & Yes & Yes & Yes & Yes & No & No \\
\hline $\begin{array}{l}\text { National level legal and } \\
\text { regulatory framework }\end{array}$ & Yes & Yes & Yes & Yes & No & No \\
\hline Institutional arrangement & Yes & Yes & Yes & Yes & No & No \\
\hline Integrated energy planning & Yes & Yes & Yes & Yes & No & No \\
\hline Public participation & Yes & Yes & yes & Yes & No & No \\
\hline $\begin{array}{l}\text { In-country solar energy } \\
\text { data management }\end{array}$ & Yes & Yes & Yes & Yes & No & No \\
\hline \multirow{4}{*}{$\begin{array}{l}\text { Main Challenges facing } \\
\text { solar power development }\end{array}$} & $\begin{array}{l}\text { Least Cost Development } \\
\text { Plan excludes solar and } \\
\text { limits its usage to off-grid } \\
\text { use in rural areas }\end{array}$ & $\begin{array}{l}\text { Least Cost Development } \\
\text { Plan excludes solar and } \\
\text { limits its usage to off-grid } \\
\text { use in rural areas }\end{array}$ & $\begin{array}{l}\text { Least Cost Development } \\
\text { Plan excludes solar and } \\
\text { limits its usage to off-grid } \\
\text { use in rural areas }\end{array}$ & $\begin{array}{l}\text { Least Cost Development } \\
\text { Plan excludes solar and } \\
\text { limits its usage to off-grid } \\
\text { use in rural areas }\end{array}$ & & \\
\hline & Limited awareness & Limited awareness & Limited awareness & Limited awareness & Limited awareness & Limited awareness \\
\hline & Limited technical expertise & Limited technical expertise & Limited technical expertise & Limited technical expertise & Limited technical expertise & Limited technical expertise \\
\hline & $\begin{array}{l}\text { Lack of adequate financing } \\
\text { of solar investments }\end{array}$ & $\begin{array}{l}\text { Lack of adequate financing } \\
\text { of solar investments }\end{array}$ & $\begin{array}{l}\text { Lack of adequate financing } \\
\text { of solar investments }\end{array}$ & $\begin{array}{l}\text { Lack of adequate financing } \\
\text { of solar investments }\end{array}$ & $\begin{array}{l}\text { Lack of adequate financing } \\
\text { of solar investments }\end{array}$ & $\begin{array}{c}\text { Lack of adequate financing } \\
\text { of solar investments }\end{array}$ \\
\hline
\end{tabular}


Overall, the solar power contribution to regional development is still small. Moreover, all EAC member states appear to face common challenges in solar power electrification, especially a persistent lack of adequate financing; lack of a common binding energy protocol or strategy for renewable energy, including solar power, similar to the absolute obligations set by other regional bodies such as the European Union; and limited awareness of solar technologies, limited technical expertise in solar technologies, and inconsistencies in the Least Cost Development Plans, which appear to exclude solar power and confine it to use in rural areas alone, as is summarized in Table 4. However, generally, the future of regional integration and cooperation for development through electrification projects by solar power looks promising, given the many similarities in renewable energy policy objectives (see Table 4).

\section{Conclusions}

Electrification by solar power has positive socioeconomic and environmental impacts, and it is increasingly pursued globally to achieve balanced regional development. Consequently, many countries are reviewing their energy policies to jointly incorporate regulatory and voluntary incentive mechanisms to harness the exploitation and development of solar power resources. Feed-in-tariff policy incentives have been the most important and promising policy approach for promoting regional solar power development projects. Other preconditions necessary for regional solar power development include goodwill from the government, capital financing opportunities for investors, the presence of local and international private solar companies, and a common binding protocol for regional development. The six East African countries exemplify these preconditions, showing that the region is poised to enjoy solar power proliferation benefits as it transitions toward an integrated greener economy, following the development of policies and establishment of institutions that favor the development of solar power resources. The development of a power master plan for the period 2013 to 2038 and the establishment of the EAC Secretariat on Energy and the East African Centre for Renewable Energy and Energy Efficiency are some of the overt indicators promoting regional development through solar power.

In addition, four (Kenya, Uganda, Tanzania, and Rwanda) of the six EAC countries have adopted FIT policies to enhance regional solar power development. Interestingly, this study also identified the formation and operation of in-country renewable energy associations targeting solar power development to be a key factor driving solar power proliferation in the region. Five countries (Kenya, Rwanda, Tanzania, Uganda, and Burundi) have solar power associations or associations related to promoting renewable energy resources. However, some EAC member states appear to be progressing faster toward regional integration through solar electrification than others. Rwanda is more robust in its quest to promote regional development through solar electrification, targeting villages in Uganda on its border. It presents many opportunities for piloting the development of regional solar power grids under the EAC framework. However, other countries like Kenya have been accused of being lukewarm toward solar power development. Nonetheless, we observe that the country appears to be more committed to in-country solar power investments, as demonstrated by government goodwill and policy orientation. In general, the contribution of solar power to regional development is still small. Still, the establishment of the East African Centre for Renewable Energy and Energy Efficiency (EAC REEE) will determine the future efforts aimed at promoting electrification by solar power in the region. Unfortunately, all states appear to be experiencing similar socioeconomic, policies and technological challenges to regional electrification by solar power. Thus, this paper recommends the following measures:

- Establish a common binding protocol for promoting cooperation and joint implementation of regional solar power investments under the East African Centre for Renewable Energy and Energy Efficiency;

- Pilot the establishment of regional solar power grids under the East African Centre for Renewable Energy and Energy Efficiency framework; 
- Conduct more studies on the correlation between selected economic growth indicators and the proliferation of solar technologies;

- Improve public awareness of the socioeconomic benefits of regional solar power investments; and

- Promote the activities of solar power and renewable energy associations as forums for hastening regional development.

\begin{abstract}
Author Contributions: Conceptualization, S.N.C.; methodology, S.N.C.; formal analysis, S.N.C.; investigation, S.N.C.; resources, S.N.C.; writing—original draft preparation, S.N.C.; writing-review and editing, C.Y.; visualization, C.Y.; supervision, C.Y.; project administration, C.Y. All authors have read and agreed to the published version of the manuscript.
\end{abstract}

Funding: This work was supported by the Ministry of Education of the Republic of Korea and the National Research Foundation of Korea (NRF-2020S1A5C2A01092978).

Institutional Review Board Statement: Not applicable.

Informed Consent Statement: Not applicable.

Data Availability Statement: Not applicable.

Conflicts of Interest: The authors declare no conflict of interest.

\title{
References
}

1. Harvey, L.D. A Handbook on Low-Energy Buildings and District-Energy Systems: Fundamentals, Techniques and Examples; Routledge: Oxfordshire, UK, 2012.

2. IEA. Energy for All: Financing Access for the Poor. Special Early Excerpt of the World Energy Outlook. In First Presented at the Energy for All-Conference in Oslo, Norway in October 2011, OECD/IEA. 2011. Available online: https://webstore.iea.org/weospecial-report-2011-energy-for-all (accessed on 18 December 2020).

3. IRENA. Cost Reduction Potentials for Solar and Wind to 2025, IRENA, Abu Dhabi. 2016. Available online: https: //www.photovoltaic-conference.com/images/2016/2_Programme/parallel_events/SolarPvChangingEnergySystem/ Michael_TAYLOR.pdf (accessed on 15 March 2021).

4. IRENA. Renewable Energy and Jobs_Annual Review 2017, IRENA, Abu Dhabi. 2017. Available online: https://www.irena.org/-/ media/Files/IRENA/Agency/Publication/2017/May/IRENA_RE_Jobs_Annual_Review_2017.pdf (accessed on 15 March 2021).

5. International Renewable Energy Agency (IRENA) Website. Available online: https://www.irena.org/ (accessed on 18 December 2020).

6. Sinha, A.; Lahiri, R.; Byabortta, S.; Chowdhury, S.; Crussley, P. Formulation of Pricing Mechanism for Microgrid Energy. 2008. Available online: https:/ / citeseerx.ist.psu.edu/viewdoc/download?doi=10.1.1.1090.7844\&rep=rep1\&type=pdf (accessed on 15 March 2021).

7. Wong, S. Overcoming obstacles against effective solar lighting interventions in South Asia. Energy Policy 2012, 40, 110-120. [CrossRef]

8. Mitigation, C.C. IPCC Special Report on Renewable Energy Sources and Climate Change Mitigation. Renew. Energy 2011, 20. Available online: https://archive.ipcc.ch/pdf/special-reports/srren/SRREN_FD_SPM_final.pdf (accessed on 15 March 2021).

9. Panwar, N.L.; Kothari, S.; Kaushik, S.C. Techno-economic evaluation of masonry type animal feed solar cooker in rural areas of an Indian state Rajasthan. Energy Policy 2013, 52, 583-586. [CrossRef]

10. Edenhofer, O.; Pichs-Madruga, R.; Sokona, Y.; Seyboth, K.; Kadner, S.; Zwickel, T.; Eickemeier, P.; Hansen, G.; Schlömer, S.; von Stechow, C.; et al. (Eds.) Renewable Energy Sources and Climate Change Mitigation: Special Report of the Intergovernmental Panel on Climate Change; Cambridge University Press: New York, NY, USA, 2011.

11. IRENA. Perspectives for the Energy Transition-Investment Needs for a Low-Carbon Energy System, Abu Dhabi. 2017. Available online: https://www.irena.org/_/media/Files/IRENA/Agency/Publication/2017/Mar/Perspectives_for_the_Energy_ Transition_2017.pdf (accessed on 15 March 2021).

12. IRENA. Renewable Energy Benefits: Leveraging Local Capacity for Onshore Wind; IRENA: Abu Dhabi, United Arab Emirates, 2017.

13. Ren21, Renewables. Global Status Report. In Agence Internationale de L'énergie, Renewables Information; Éditions OCDE, 21: Paris, France, 2014.

14. Haas, R.; Resch, G.; Panzer, C.; Busch, S.; Ragwitz, M.; Held, A. Efficiency and effectiveness of promotion systems for electricity generation from renewable energy sources-Lessons from EU countries. Energy 2011, 36, 2186-2193. [CrossRef]

15. Ayoub, N.; Yuji, N. Governmental intervention approaches to promote renewable energies-Special emphasis on Japanese feed-in tariff. Energy Policy 2012, 43, 191-201. [CrossRef]

16. Milanés-Montero, P.; Arroyo-Farrona, A.; Pérez-Calderón, E. Assessment of the Influence of Feed-In Tariffs on the Profitability of European Photovoltaic Companies. Sustainability 2018, 10, 3427. [CrossRef]

17. Lesser, J.A.; Su, X. Design of an economically efficient feed-in tariff structure for renewable energy development. Energy Policy 2008, 36, 981-990. [CrossRef] 
18. Knopf, B.; Nahmmacher, P.; Schmid, E. The European renewable energy target for 2030-An impact assessment of the electricity sector. Energy Policy 2015, 85, 50-60. [CrossRef]

19. Oil Price Website. 2020. Available online: https://oilprice.com/Alternative-Energy/Renewable-Energy/ (accessed on 24 November 2020).

20. ESI Africa Website. Available online: https://www.esi-africa.com/ (accessed on 18 December 2020).

21. Zoellner, J.; Schweizer-Ries, P.; Wemheuer, C. Public acceptance of renewable energies: Results from case studies in Germany. Energy Policy 2008, 36, 4136-4141. [CrossRef]

22. Nie, D.; Panfilova, E.; Samusenkov, V.; Mikhaylov, A. E-Learning Financing Models in Russia for Sustainable Development. Sustainability 2020, 12, 4412. [CrossRef]

23. Paré, G.; Trudel, M.C.; Jaana, M.; Kitsiou, S. Synthesizing information systems knowledge: A typology of literature reviews. Inf. Manag. 2015, 52, 183-199. [CrossRef]

24. Sylvester, A.; Tate, M.; Johnstone, D. Beyond synthesis: Representing heterogeneous research literature. Behav. Inf. Technol. 2013, 32, 1199-1215. [CrossRef]

25. Templier, M.; Paré, G. A framework for guiding and evaluating literature reviews. Commun. Assoc. Inf. Syst. 2015, 37, 6. [CrossRef]

26. National Energy Policy for Kenya. 2012. Available online: https://www.kplc.co.ke/img/full/bWXFzkYGyS97_National_ Energy_Policy_-_Third_Draft_-_May_11_2012.pdf (accessed on 13 November 2020).

27. Draft Energy (Solar PV Systems) Regulations for Kenya. 2020. Available online: https://www.epra.go.ke/the-draft-energy-solarphotovoltaic-systems-regulations-2020/ (accessed on 16 November 2020).

28. National Energy Policy of Tanzania. 2015. Available online: http://www.ewura.go.tz/wp-content/uploads/2016/08/NationalEnergy-Policy.pdf (accessed on 11 October 2020).

29. Draft Energy Policy for Uganda. 2019. Available online: https://www.energyandminerals.go.ug/site/assets/files/1081/draft revised_energy_policy_-_11_10_2019-1_1.pdf (accessed on 12 November 2020).

30. Energy Policy for Rwanda. 2015. Available online: https://www.iea.org/policies/7993-rwanda-energy-policy?technology= Solar\%20thermal\%20heaters (accessed on 16 December 2020).

31. Solar Energy Regulations for Rwanda. 2014. Available online: https://www.reg.rw/fileadmin/user_upload/Final_ESSP.pdf (accessed on 17 December 2020).

32. Energy Law No. 1/014 of Burundi. Available online: https://energypedia.info/wiki/Burundi_Energy_Situation (accessed on 20 December 2020).

33. National Electric Sector Policy of South Sudan. 2007. Available online: https://www.afdb.org/fileadmin/uploads/afdb/ Documents / Generic-Documents /South\%20Sudan\%20Infrastructure\%20Action\%20Plan\%20-\%20\%20A\%20Program\%20for\% 20Sustained \%20Strong\%20Economic\%20Growth\%20-\%20Chapter\%208\%20-\%20Provision \%20of \%20Electricity \%20and \%20 Rural\%20Energy.pdf (accessed on 21 December 2020).

34. East African Community (EAC 2014). Regional Scoping Study to Identify Potential Areas for Intervention by the EAC Secretariat on Renewable Energy and Energy Efficiency. Available online: http:/ / eacgermany.org/wp-content/uploads/2014/10/EAC\%20 Renewable\%20Energy\%20and\%20Energy\%20Efficiency.pdf (accessed on 19 November 2020).

35. Hamad, H. Neo-Functionalism': Relevancy for East African Community Political Integration? Africology J. Pan Afr. Stud. 2016, 9, 13

36. MaRS Website. 2020. Available online: https://www.marsdd.com/news/east-africa-solar-power-innovations/ (accessed on 15 December 2020).

37. Regional Solar Power Taxation Handbook for East Africa. 2020. Available online: https://www.useaug.org/sites/default/files/ resources/the_east_african_regional_handbook_on_solar_taxation_0.pdf (accessed on 15 December 2020).

38. Kenya National Bureau of Statistics Census Report for 2019. Available online: https:/ /www.knbs.or.ke/?wpdmpro=2019-kenyapopulation-and-housing-census-volume-i-population-by-county-and-sub-county (accessed on 18 December 2020).

39. EPPRA Website. 2020. Available online: https://www.epra.go.ke/download/draft-energy-solar-photovoltaic-systemsregulations-2019/ (accessed on 13 December 2020).

40. PV Magazine. 2020. Available online: https://www.pv-magazine.com/2019/09/02/kenyan-government-blamed-for-sluggishprogress-of-solar/ (accessed on 16 November 2020).

41. Feed-In-Tarrif for Kenya (FIT). Available online: https:/ / kerea.org/wp-content/uploads/2012/12/Feed-in-Tariff-Policy-2010 .pdf (accessed on 16 November 2020).

42. M-Kopa Solar Company Website. 2020. Available online: https://m-kopa.com/kenya/impact/ (accessed on 15 December 2020).

43. EPRA Press Release. 2020. Available online: https://www.epra.go.ke/press-release-on-misinformation-on-the-draft-energysolar-photovoltaic-systems-regulations-2020/ (accessed on 13 December 2020).

44. Owen, M.; van der Plas, R.; Sepp, S. Can there be energy policy in Sub-Saharan Africa without biomass? Energy Sustain. Dev. 2013, 17, 146-152. [CrossRef]

45. Rwanda Energy Group Website. 2020. Available online: https://www.reg.rw/what-we-do/generation/solar/\#: \{\}:text= Currently\%2C\%20Rwanda \T1 \textquoterights\%20total\%20on\%2Dgrid,Solar\%20plant\%20generating \%203.3\%20MW (accessed on 19 November 2020).

46. Ministry of Infrastructure of Rwanda (MINIFRA) Website. 2020. Available online: https://www.mininfra.gov.rw/index.php?id= 85 (accessed on 19 November 2020). 
47. The East African Newspaper of July 2014. Available online: https://www.theeastafrican.co.ke/tea/rwanda-today/rwanda-setsrules-for-solar-water-heaters-market--1365468 (accessed on 13 December 2020).

48. Energy Sector Strategic Plan for Rwanda (ESSPR 2013-2018). Available online: https://www.mininfra.gov.rw/fileadmin/user_ upload/ESSP_March_2015.pdf (accessed on 19 November 2020).

49. AFSIA Website. 2020. Available online: http:/ / afsiasolar.com/about-us/who-we-are/ (accessed on 15 December 2020).

50. Gudo, A.A.; Belete, M.; Abubakar, G.A.; Deng, J. Spatio-Temporal Analysis of Solar Energy Potential for Domestic and Agricultural Utilization to Diminish Poverty in Jubek State, South Sudan, Africa. Energies 2020, 13, 1399. [CrossRef]

51. Ayik, A.; Ijumba, N.; Kabiri, C.; Goffin, P. Selection of Off-Grid Renewable Energy Systems Using Analytic Hierarchy Process: Case of South Sudan. In Proceedings of the 2020 IEEE PES/IAS PowerAfrica, Nairobi, Kenya, 25-28 August 2020; pp. 1-5.

52. USIP. Special Report: South Sudan's Renewable Energy Potential. 2018. Available online: https://www.usip.org/sites/default/ files/2018-01/sr418-south-sudans-renewable-energy-potential-a-building-block-for-peace.pdf (accessed on 19 November 2020).

53. PV Magazine. 2019. Available online: https://www.pv-magazine.com/2019/09/17/south-sudan-to-embrace-renewables/ (accessed on 19 November 2020).

54. Rabah, A.A.; Nimer, H.B.; Doud, K.R.; Ahmed, Q.A. Modelling of Sudan's Energy Supply, Transformation, and Demand. J. Energy 2016, 2016. [CrossRef]

55. Omer, A.M. Evaluation of sustainable development and environmentally friendly energy systems: Case of Sudan. J. Environ. Res. Manag. 2015, 6, 237-261.

56. Aly, A.; Moner-Girona, M.; Szabó, S.; Pedersen, A.B.; Jensen, S.S. Barriers to large-scale solar power in Tanzania. Energy Sustain. Dev. 2019, 48, 43-58. [CrossRef]

57. Ondraczek, J. The sun rises in the east (of Africa): A comparison of the development and status of solar energy markets in Kenya and Tanzania. Energy Policy 2013, 56, 407-417. [CrossRef]

58. IRENA and LBNL, Renewable Energy Zones for The Africa Clean Energy Corridor. Multi-Criteria Analysis for Planning Renewable Energy, IRENA, Abu Dhabi, United Arab Emirates. 2015. Available online: https://www.irena.org/-/media/Files/ IRENA/Agency/Publication/2015/IRENA-LBNL_Africa-RE-_CEC_2015.pdf (accessed on 15 March 2021).

59. Hansen, U.E.; Pedersen, M.B.; Nygaard, I. "Review of Solar PV Market Development in East Africa”, United Nations Environment Programme. 2014. Available online: http:/ / pubdocs.worldbank.org/en/600611475093991341/Solar-PV-market-East-AfricaUNEP-2014.pdf (accessed on 15 March 2021).

60. TANESCO. Tanzanian solar PV-hybrid. In Presentation at the Tanzanian Solar PV-Hybrid Workshop; Tsakhara, P., Ed.; TANESCO: Berlin, Germany, 2015.

61. IRENA. Renewables Readiness Assessment Report. 2017. Available online: https://www.irena.org/- / media/Files /IRENA/ Agency/Publication/2017/May/IRENA_RRA_UR_Tanzania_2017.pdf (accessed on 19 November 2020).

62. Groenewoudt, A.C.; Romijn, H.A.; Alkemade, F. From fake solar to full service: An empirical analysis of the solar home systems market in Uganda. Energy Sustain. Dev. 2020, 58, 100-111. [CrossRef]

63. D'Couto, H.; Mugerwa, J.; Tayebwa, M.; Nuwagira, E.; Muyanja, D.; Kakuhikire, B.; Vallarino, J. Impact of a Solar Lighting Interventional Trial on Non-Health Outcomes in Rural Uganda: A Mixed Methods Study. In B50. Asbestos, Beryllium, And Other Unique Inhaled Toxicants; American Thoracic Society: New York, NY, USA, 2020; p. A3649.

64. USEAUG Website. 2020. Available online: https:/ / www.useaug.org/about/overview (accessed on 15 December 2020).

65. Nsabimana, R. Electricity sector organization and performance in Burundi. In Multidisciplinary Digital Publishing Institute Proceedings; MDPI: Basel, Switzerland, 2020; Volume 58, p. 26.

66. Müller, F.; Claar, S.; Neumann, M.; Elsner, C. Is green a Pan-African colour? Mapping African renewable energy policies and transitions in 34 countries. Energy Res. Soc. Sci. 2020, 68, 101551. [CrossRef]

67. Ministry of Energy and Mines of Burundi (MoEM 2012). Report on Investment Opportunities in Renewable Energy Burundi. Available online: http:/ / proreds.eu/wp-content/uploads/2014/02/Investment-opportunities-in-renewable-energy-Burundi. pdf (accessed on 19 November 2020).

68. Energy Strategy and Action Plan for Burundi (EUEI 2009). Available online: http://www.euei-pdf.org/sites/default/files/field_ publication_file/FF_EUEI_PDF_Burundi_Energy_strategy_Nov2009_EN.pdf (accessed on 19 November 2020).

69. BUREA Website. 2020. Available online: https://www.gogla.org/about-us/members/burundi-renewable-energy-associationburea\#: \{\}:text=Burundi\%20Renewable\%20Energy \%20Association\%20(BUREA) $\% 20$ is $\% 20 a \% 20$ non $\% 2$ Dprofit,energy $\% 20 f o r \%$ 20all\%20in\%20Burundi (accessed on 15 December 2020).

70. Yumashev, A.; Ślusarczyk, B.; Kondrashev, S.; Mikhaylov, A. Global Indicators of Sustainable Development: Evaluation of the Influence of the Human Development Index on Consumption and Quality of Energy. Energies 2020, 13, 2768. [CrossRef]

71. United Nations Environment Programme (UNEP). Global Trends in Sustainable Energy Investment. Analysis of Trends and Issues in the Financing of Renewable Energy and Energy Efficiency. 2008. Available online: https://wedocs.unep.org/bitstream/ handle/20.500.11822/8821/Global_Trends_08.pdf?sequence=3\&isAllowed=y (accessed on 18 December 2020). 